\title{
MATURATION IN VITRO OF OVARIAN OOCYTES OF PREPUBERTAL AND ADULT HAMSTERS
}

\author{
T. IWAMATSU* AND R. YANAGIMACHI \\ Department of Anatomy and Reproductive Biology, \\ University of Hawaii School of Medicine, Honolulu, Hawaii 96822, U.S.A.
}

(Received 16th December 1974)

\begin{abstract}
Summary. Oocytes of various sizes were isolated from ovaries of sexually mature and prepubertal hamsters and cultured to determine whether all the oocytes were capable of maturing in vitro. It was found that only the oocytes that had attained maximum size (about $80 \mu \mathrm{m}$ in the vitelline diameter) were capable of undergoing maturation in vitro. Smaller oocytes ( $<80 \mu \mathrm{m}$ in diameter) failed either to initiate or to complete maturation. The oocytes which were capable of maturing in vitro (competent oocytes) were present in the ovaries of adult females 136 to $138 \mathrm{hr}$ before ovulation. The competent oocytes first appeared in the ovaries of prepubertal females on the 23rd day after birth, about 10 days before puberty.
\end{abstract}

\section{INTRODUGTION}

Hamster oogonia begin the first meiotic division upon the birth of the animal and soon enter a prolonged resting phase known as the dictyate or dictyotene stage (Greenwald \& Peppler, 1968; Lemon \& Morton, 1968; Challoner, 1974), which is distinctively characterized by the presence of a nucleus known as the germinal vesicle. The resumption of meiotic division occurs in the sexually mature females by an LH-mediated stimulation shortly before ovulation. At ovulation, the oocytes are in the metaphase of the second meiotic division (metaphase II). This nuclear progression from the dictyate to metaphase II stage is commonly known as nuclear maturation or just maturation. In all mammals so far studied, dictyate oocytes in the ovary of the adult female resume meiotic division when they are removed from the ovary and placed in appropriate culture media (Donahue, 1972; Biggers, 1973; Fowler \& Edwards, 1973), and hamster oocytes are no exception (Edwards, 1962; Gwatkin \& Haidri, 1973). This study was initiated to determine (1) whether all the ovarian oocytes in the adult hamster are capable of undergoing spontaneous maturation in vitro and (2) when the oocytes capable of maturing in vitro (competent oocytes) first appear in the ovary of prepubertal females.

* Present address: Department of Biology, Aichi University of Education, Igaya-cho, Kariya, Aichiken, Japan. 


\section{MATERIALS AND METHODS}

\section{Animals}

Golden hamsters were bred and maintained in an air-conditioned room with light provided automatically from 06.00 to 18.00 hours. Female hamsters in the colony showed their first oestrus and ovulation at an average of 34 days after birth (Diamond \& Yanagimachi, 1970). Adult hamsters had regular 4-day cycles and ovulated in the early morning (usually between 02.00 and 04.00 hours) on Day 1 of each oestrous cycle. The morning of Day 1 was characterized by a thick homogenous vaginal discharge (Greenwald, 1960). All animals came into oestrus in the evening of Day 4.

\section{Determination of time of oocyte maturation in adult females}

Intact adult females in one group were killed at various times during Day 4 of the oestrous cycle. The adult females in another group were injected intraperitoneally with 20 to 30 i.u. HCG (Ayerst Laboratories, New York) between 08.00 and 10.00 hours on Day 4 and killed between 1 and $12 \mathrm{hr}$ after the injection. The ovaries were placed in $0.85 \% \mathrm{NaCl}$ and dissected with a pair of needles to release the oocytes from preovulatory follicles. After the oocytes were freed from the surrounding cumulus cells by being sucked in and out of a small-bore pipette (i.d. 70 to $80 \mu \mathrm{m}$ ), they were mounted between a slide and coverslip, fixed with $10 \%$ neutral formalin for $24 \mathrm{hr}$, stained with $0.25 \%$ aceto-lacmoid (Iwamatsu \& Chang, 1972) and the condition of the nucleus of each oocyte was examined with a phase-contrast microscope. The nuclear stages of the oocytes were classified according to the criteria of Donahue (1968a).

\section{Culture medium}

The culture medium used in this study was similar to that described by Gwatkin \& Haidri (1973) with these modifications: $117 \cdot 3$ mm-sodium chloride, 2.7 mm-calcium chloride, $22.3 \mathrm{~mm}$-sodium lactate and $4 \mathrm{mg}$ bovine serum albumin (fraction V, Reheis/Armour, New York)/ml in place of polyvinylpyrrolidone. The medium had an osmolality of approximately $310 \mathrm{mosmol}$ and $\mathrm{pH}$ value of about 7.3 when equilibrated with $5 \% \mathrm{CO}_{2}+5 \% \mathrm{O}_{2}+90 \% \mathrm{~N}_{2}$. After sterilizing by filtering through a 'millipore' filter (pore size $0.45 \mu \mathrm{m}$ ), the medium was stored at $4^{\circ} \mathrm{G}$ and used for experiments within 1 week.

\section{Collection and culture of ovarian oocytes}

Adult ( 8 to 10 weeks old) and prepubertal females (20 to 24 days old) were killed by cervical dislocation. Their ovaries were then removed and placed in a watchglass containing the culture medium. Follicles were carefully dissected out of the thecae by means of a pair of sharp stainless steel needles. Atretic follicles, which were recognized by the opacity of the granulosa cell layers, were discarded. After the diameter of each follicle was measured, the follicle was broken with a needle to release the oocyte surrounded by tightly packed follicular cells. Some oocytes were freed from the follicular cells by repeatedly sucking them in and out of a small-bore pipette (i.d. 70 to $80 \mu \mathrm{m}$ ) and the diameter of the vitellus of each oocyte was determined. The oocytes with and without follicular 
cells were rinsed with the culture medium and placed in $0.2 \mathrm{ml}$ fresh culture medium in the central well of a plastic organ tissue culture dish (Falcon Plastics, Oxnard, California). The surface of the culture medium was immediately covered with mineral oil (Squibb \& Sons, Princeton, New Jersey). After the preparation was incubated at $37^{\circ}$ to $38^{\circ} \mathrm{C}$ for 3 to $12 \mathrm{hr}$ under $5 \% \mathrm{CO}_{2}+5 \% \mathrm{O}_{2}$ $+90 \% \mathrm{~N}_{2}$, the oocytes were rinsed with $0.85 \% \mathrm{NaCl}$ and any follicular cells surrounding the oocytes were removed by means of a small-bore pipette. The oocytes were fixed and stained, and then examined with a phase-contrast microscope for the condition of their nuclei.

\section{RESULTS}

Size relationship between follicles and oocytes in the ovary of the adult hamster

The ovaries of adult females contained numerous growing follicles. The diameters of the preovulatory follicles in the morning (09.00 to 10.00 hours)

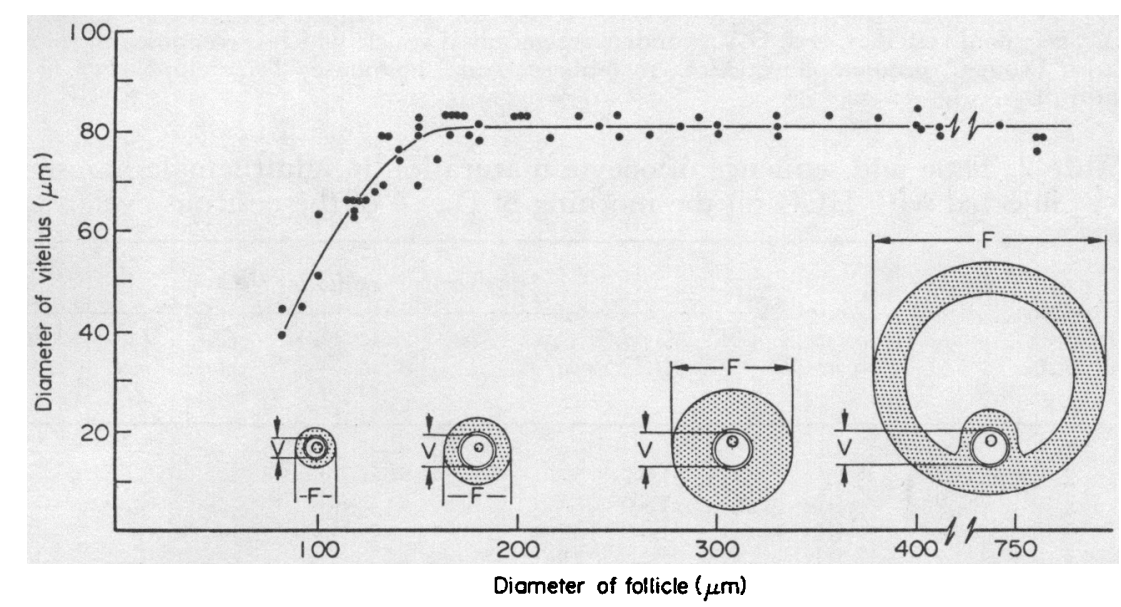

Texr-FIG. 1. Size relationship between follicles and oocytes in the ovaries of five adult female hamsters. F, diameter of follicle; V, diameter of vitellus.

on Day 1 and Day 4 were $552 \pm 17 \mu \mathrm{m}$ and $710 \pm 14 \mu \mathrm{m}$ (mean \pm S.E.), respectively. The diameters of the oocytes themselves (the vitellus only of the oocytes, not including the zona pellucida) in these follicles were approximately $80 \mu \mathrm{m}$ regardless of the size of the follicles. The diameters of the oocytes from small follicles (200 to $300 \mu \mathrm{m}$ ) were the same as those of the oocytes from preovulatory follicles. Very small follicles (90 to $120 \mu \mathrm{m}$ ) contained small oocytes (40 to $60 \mu \mathrm{m})$. The size relationship between the follicle and oocyte in the ovary of the adult hamster is summarized in Text-fig. 1.

Time and sequence of oocyte maturation in vivo

All oocytes collected from large preovulatory follicles at 14.00 hours on Day 4 of the oestrous cycle were in the germinal vesicle stage. Breakdown of the germinal vesicle began at approximately 16.00 hours and maturation of the 
oocytes was completed by 02.00 hours the next morning (Table 1 ). When females were injected with HCG in the morning ( 08.00 to 10.00 hours) on Day 4 , breakdown of the germinal vesicle started 2 to $3 \mathrm{hr}$ later and the maturation of the oocytes was completed within the next 9 to $10 \mathrm{hr}$ (Table 2).

Table 1. Time and sequence of oocyte maturation in intact adult female hamsters

\begin{tabular}{|c|c|c|c|c|c|c|c|c|c|c|c|c|}
\hline \multirow{2}{*}{$\begin{array}{c}\text { Day of } \\
\text { oestrous } \\
\text { cycle }\end{array}$} & \multirow{2}{*}{$\begin{array}{c}\text { Time of } \\
\text { day } \\
\text { (hours) }\end{array}$} & \multirow{2}{*}{$\begin{array}{l}\text { No. of } \\
\text { animals }\end{array}$} & \multirow{2}{*}{$\begin{array}{c}\text { No. of } \\
\text { oocytes } \\
\text { examined }\end{array}$} & \multicolumn{9}{|c|}{$\%$ of oocytes * exhibiting: } \\
\hline & & & & G.V. & $\begin{array}{l}\text { Cond. } \\
G . V .\end{array}$ & $\begin{array}{c}\text { Pro- } \\
\text { met. I }\end{array}$ & $\underset{I}{M e t .}$ & Ana. & Tel. & $\begin{array}{l}\text { Chr. } \\
\text { Mass }\end{array}$ & $\begin{array}{l}\text { Pro- } \\
\text { met. } \\
I I\end{array}$ & $\underset{I I}{M e t .}$ \\
\hline Day 4 & $\begin{array}{l}14.00 \\
16.00 \\
19.00 \\
22.00 \\
24.00\end{array}$ & $\begin{array}{r}6 \\
10 \\
10 \\
4 \\
4\end{array}$ & $\begin{array}{l}40 \\
77 \\
60 \\
21 \\
21\end{array}$ & $\begin{array}{c}100 \cdot 0 \\
97 \cdot 4 \\
- \\
- \\
-\end{array}$ & $\begin{array}{c}- \\
2 \cdot 6 \\
70 \cdot 0 \\
- \\
-\end{array}$ & $\frac{\bar{C}}{30 \cdot 0} \overline{-}$ & $\frac{-}{47 \cdot 6}$ & $\overline{-}$ & $\bar{Z} \frac{}{\overline{52 \cdot 4}}$ & $\overline{-}$ & $\overline{-}$ & $\begin{array}{l}- \\
- \\
-\end{array}$ \\
\hline Day 1 & 02.00 & 5 & 30 & - & - & - & - & - & - & - & - & $100 \cdot 0$ \\
\hline
\end{tabular}

* G.V., germinal vesicle; Cond. G.V., condensing germinal vesicle which is composed of condensing chromatin; Promet., prometaphase; Met., metaphase; Ana., anaphase; Tel., telophase; Chr. Mass, chromatin mass.

Table 2. Time and sequence of oocyte maturation in adult female hamsters injected with HCG on the morning of Day 4 of the oestrous cycle

\begin{tabular}{|c|c|c|c|c|c|c|c|c|c|c|c|}
\hline \multirow{2}{*}{$\begin{array}{l}\text { Time after } \\
\text { injection } \\
\text { of } H C G\end{array}$} & \multirow{2}{*}{$\begin{array}{l}\text { No. of } \\
\text { animals }\end{array}$} & \multirow{2}{*}{$\begin{array}{c}\text { No. of } \\
\text { oocytes } \\
\text { examined }\end{array}$} & \multicolumn{9}{|c|}{$\%$ of oocytes* exhibiting: } \\
\hline & & & $G . V$. & $\begin{array}{l}\text { Cond. } \\
G . V .\end{array}$ & $\begin{array}{c}\text { Pro } \\
\text { met. } I\end{array}$ & $\underset{I}{M e t}$ & Ana. & Tel. & $\begin{array}{l}\text { Chr. } \\
\text { Mass }\end{array}$ & $\begin{array}{l}\text { Pro- } \\
\text { met. } \\
\text { II }\end{array}$ & $\underset{I I}{\text { Met. }}$ \\
\hline 1 & 2 & 15 & $100 \cdot 0$ & - & - & - & - & - & - & - & - \\
\hline 2 & 2 & 12 & $83 \cdot 3$ & 16.7 & - & - & 一 & - & - & - & - \\
\hline 3 & 2 & 16 & $25 \cdot 0$ & $75 \cdot 0$ & - & - & - & - & - & - & - \\
\hline 4 & 2 & 18 & - & - & $100 \cdot 0$ & - & - & - & - & - & - \\
\hline 7 & 2 & 16 & - & - & $75 \cdot 0$ & 25.0 & - & - & 一 & - & - \\
\hline 8 & 2 & 15 & - & 一 & - & 33.3 & $66 \cdot 7$ & - & - & - & - \\
\hline 9 & 2 & 15 & - & - & - & - & 33.3 & 66.7 & - & - & - \\
\hline 10 & 2 & 21 & - & - & - & - & - & $28 \cdot 6$ & $71 \cdot 4$ & - & - \\
\hline 11 & 2 & 16 & - & - & - & - & - & $6 \cdot 3$ & $12 \cdot 5$ & $81 \cdot 2$ & - \\
\hline 12 & 2 & 21 & - & - & - & - & - & - & - & - & $100 \cdot 0$ \\
\hline
\end{tabular}

* See Table 1 for abbreviations.

Maturation in vitro of ovarian oocytes isolated from adult females

A total of 514 oocytes were liberated from the ovaries of sixty adult females and cultured in vitro. Before culture, all the oocytes were in the germinal vesicle stage. The oocytes estimated to be at stages approximately 16 to $138 \mathrm{hr}$ before ovulation had diameters of about $80 \mu \mathrm{m}$ and approximately $90 \%$ of them had completed maturation by $12 \mathrm{hr}$ after the start of culture (Table 3 ). The removal of follicular cells from these oocytes did not appear markedly to affect the rate of maturation (Table 3). Small oocytes (70 to $78 \mu \mathrm{m}$ diameter) from small follicles (128 to $166 \mu \mathrm{m}$ ) failed to mature, although in 11 to $13 \%$ of them, the germinal vesicles broke down. An interesting finding was that some of the 


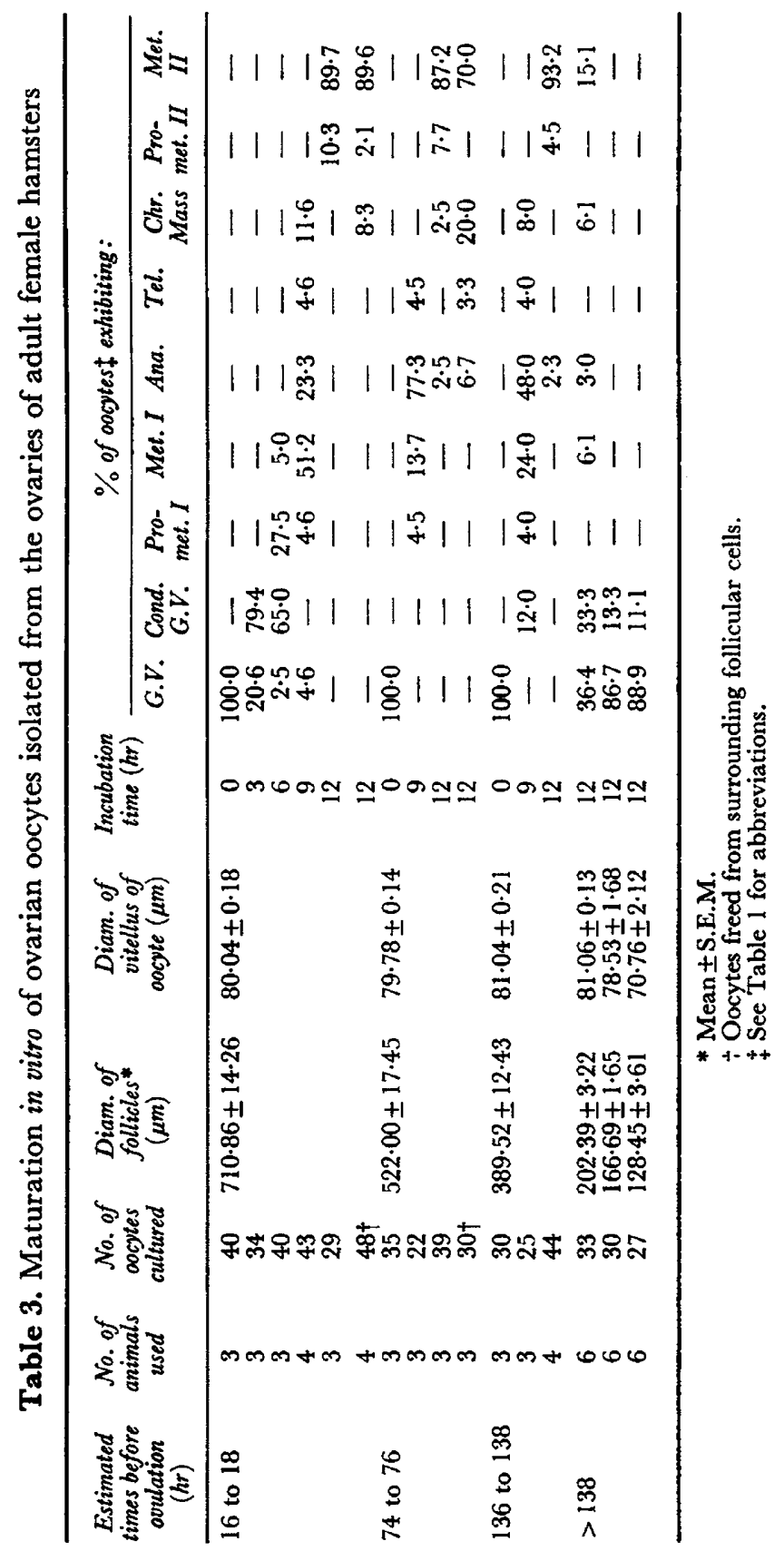


oocytes in small follicles were as large as the oocytes in preovulatory follicles and were capable of maturing in vitro (Table 3 ).

\section{Maturation in vitro of ovarian oocytes isolated from prepubertal females}

Ovaries of 20- and 22-day-old females contained only small follicles (about $150 \mu \mathrm{m}$ or less in diameter) and none of the oocytes from these follicles matured in vitro (Table 4). Some follicles $>200 \mu \mathrm{m}$ in diameter were found in the ovaries of 23- and 24-day-old females, and many of the oocytes from these follicles did mature in vitro (Table 4). The data presented in Table 4 show that the oocytes became competent to undergo maturation in vitro when they attained a diameter of about $80 \mu \mathrm{m}$. Such competent oocytes first appeared in the ovary on the 23rd day after birth.

Table 4. Maturation in vitro of ovarian oocytes isolated from prepubertal hamsters and examined after $12 \mathrm{hr}$ in culture

\begin{tabular}{|c|c|c|c|c|c|c|c|c|c|c|}
\hline \multirow{2}{*}{$\begin{array}{c}\text { Age of } \\
\text { animals } \\
\text { (days after } \\
\text { birth) }\end{array}$} & \multirow{2}{*}{$\begin{array}{l}\text { No. of } \\
\text { animals }\end{array}$} & \multirow{2}{*}{$\begin{array}{l}\text { No. of } \\
\text { oocytes } \\
\text { cultured }\end{array}$} & \multirow{2}{*}{$\begin{array}{c}\text { Diam. of } \\
\text { follicle* }(\mu \mathrm{m})\end{array}$} & \multirow[b]{2}{*}{$\begin{array}{c}\text { Diam. of } \\
\text { oocyte } \\
\text { vitellus* } \\
(\mu m)\end{array}$} & \multicolumn{6}{|c|}{$\%$ of oocytes $\dagger$ exhibiting: } \\
\hline & & & & & G.V. & $\begin{array}{l}\text { Cond. } \\
\text { G.V. }\end{array}$ & Met. I & $\begin{array}{l}\text { Chr. } \\
\text { mass }\end{array}$ & $\begin{array}{l}\text { Pro- } \\
\text { met. } \\
\text { II }\end{array}$ & $\begin{array}{l}\text { Met. } \\
I I\end{array}$ \\
\hline 20 & 4 & 33 & $152 \cdot 44 \pm 3 \cdot 88$ & $74.56 \pm 3.31$ & $100 \cdot 0$ & - & - & - & - & - \\
\hline 22 & 4 & 37 & $142 \cdot 23 \pm 4 \cdot 49$ & $77 \cdot 66 \pm 1 \cdot 62$ & $100 \cdot 0$ & - & - & -- & - & 一 \\
\hline \multirow[t]{2}{*}{23} & 4 & $\begin{array}{r}50 \\
8\end{array}$ & $\begin{array}{l}168 \cdot 78 \pm 13 \cdot 39 \\
282 \cdot 20 \pm 12 \cdot 27\end{array}$ & $\begin{array}{l}79 \cdot 86 \pm 1 \cdot 00 \\
81 \cdot 60+0 \cdot 37\end{array}$ & $\begin{array}{l}70 \cdot 0 \\
25 \cdot 0\end{array}$ & $\begin{array}{l}16.0 \\
12.5\end{array}$ & 6.0 & - & 二 & $\begin{array}{r}8 \cdot 0 \\
62 \cdot 5\end{array}$ \\
\hline & & 45 & 148.0 & $76.24 \pm 0.98$ & $100 \cdot 0$ & - & - & - & - & - \\
\hline \multirow[t]{2}{*}{24} & 4 & 27 & $164 \cdot 69 \pm 2$ & $81.16 \pm 0.58$ & $81 \cdot 5$ & $14 \cdot 8$ & $3 \cdot 7$ & - & - & - \\
\hline & & 22 & $251 \cdot 55 \pm 29 \cdot 71$ & $81 \cdot 84 \pm 0.39$ & $22 \cdot 7$ & $27 \cdot 3$ & $13 \cdot 6$ & $9 \cdot 1$ & $4 \cdot 5$ & $22 \cdot 7$ \\
\hline
\end{tabular}

* Mean + S.E.M.

$\dagger$ See Table 1 for abbreviations.

\section{DISCUSSION}

The present study has shown that ovarian oocytes in both sexually mature and prepubertal hamsters acquire the ability to undergo spontaneous maturation in vitro when their vitelli attain maximum size, approximately $80 \mu \mathrm{m}$ in diameter. The failure of smaller oocytes to undergo maturation in vitro suggests that some factor(s) necessary for oocyte maturation is absent or at least is not present in a sufficient amount in the cytoplasm and/or the nucleus. This factor could be RNA. According to Moore, Lintern-Moore, Peters \& Faber (1974), RNA synthesis in the mouse ovarian oocyte increases steadily with the growth of the oocyte and reaches a peak at stage 5 a (Pedersen \& Peters, 1968) of follicular development, at which stage the oocyte has almost attained maximum size. When the follicle reaches stage 8 (shortly before ovulation), RNA synthesis in the oocyte is very low or absent (Moore et al., 1974). The fact that fully grown mouse oocytes can mature in vitro in the presence of actinomycin $\mathrm{D}$ (Donahue, 1968b; cited from Stern, Rayyis \& Kennedy, 1972) may be explained by assuming that fully grown oocytes have already accumulated sufficient RNA necessary for maturation. 
The mechanisms by which fully grown oocytes are inhibited from undergoing maturation in vivo are not fully understood. Foote \& Thibault (1969) and Tsafriri \& Channing (1975) believe that the granulosa cells, not the theca cells, prevent the oocytes from maturing by producing an inhibitory substance. They have suggested that the LH surge before ovulation induces a stimulus necessary for initiating the normal maturation of the oocytes, which involves a mechanical isolation of the oocyte from its surrounding granulosa cells. It is also possible that the $\mathbf{L H}$ stimulation causes the granulosa cells to supply the oocytes with an essential nutrient which induces maturation (Biggers, 1973). According to Zeilmaker \& Verhamme (1974), rat ovarian oocytes fail to initiate maturation when they are cultured in vitro in the absence of oxygen. Thus, some simple physicochemical factor such as low oxygen tension within the follicle, could be the factor(s) which prevents the oocytes from initiating maturation.

As our data show, hamster oocytes capable of undergoing maturation in vitro (competent oocytes) first appear in the ovary on the 23rd day after birth. This corresponds to the day on which fully grown oocytes (about $80 \mu \mathrm{m}$ in diameter) first appear in the ovary. In the mouse, the competent oocytes begin to appear in the ovary on the 15th day after birth, although the oocytes are not yet fully grown at that time (Szybek, 1972). The difference between the hamster and the mouse regarding the time of the first appearance of competent oocytes may be partly due to differences in gestation period (16 days in the hamster and 19 days in the mouse) and in the time of initiation of meiotic division, i.e. about the 16th day of gestation in the mouse (Franchi et al., 1962), and within a few hours after birth in the hamster (Lemon \& Morton, 1968). The time that the competent oocytes begin to appear in the rat is not known, but that when large follicles ( $>200 \mu \mathrm{m}$ in diameter) first appear is reported to be between 10 and 15 days after birth (Reiter et al., 1972). In this context, it is interesting to recall that prepubertal rats show very high levels of blood FSH and LH between 10 and 20 days after birth (Döhler \& Wuttke, 1974). According to Kragt \& Dahlgren (1972), Ojeda \& Ramirez (1972) and Meijs-Roelofs et al. (1973), the highest levels of blood FSH and LH occur in prepubertal rats on approximately the 15 th day after birth. Although we have no evidence, it is quite possible that a similar pattern with a 'surge' in gonadotrophin secretion occurs in the prepubertal mouse and hamster. This prepubertal gonadotrophin 'surge' may be directly or indirectly related to the first appearance of the fully grown oocytes capable of undergoing maturation in vitro.

\section{ACKNOWLEDGMENTS}

This work was supported by grants from the Ford Foundation, the Population Council and U.S. Public Health Service (HD-03402). We thank Mrs C. A. Mahi for her assistance in preparing the manuscript.

\section{REFERENCES}

BIGGERs, J.D. (1973) Oogenesis and ovum maturation. In The Regulation of Mammalian Reproduction, pp. 273-285. Eds. S. J. Segal, R. Grozier, P. A. Corfman and P. G. Condliffe. Thomas, Springfield, Illinois. 
Challoner, S. (1974) Studies of oogenesis and follicular development in the golden hamster. I. A quantitative study of meiotic prophase in vitro. 7. Anat. 117, 373-383.

Diamond, M. \& Yanagimachi, R. (1970) Reproductive development in the female golden hamster in relation to spontaneous estrus. Biol. Reprod. 2, 223-229.

DöhleR, K.D. \& WUTtKe, W. (1974) Serum LH, FSH, prolactin and progesterone from birth to puberty in female and male rats. Endocrinology 94, 1003-1008.

Donahue, R.P. (1968a) Maturation of the mouse oocyte in vitro. I. Sequence and timing of nuclear progression. F. exp. Zool. 169, 237-250.

Donahue, R.P. (1968b) Maturation of the mouse oocyte in vitro. Ph.D. dissertation, Johns Hopkins University, Baltimore, Maryland. Cited by Stern, Rayyis \& Kennedy, 1972.

Donahue, R.P. (1972) The relation of oocyte maturation to ovulation in mammals. In Oogenesis, pp. 413-438. Eds. J. D. Biggers and A. W. Schuetz. University Park Press, Baltimore, Maryland.

EDWARDs, R.G. (1962) Meiosis in ovarian oocytes of adult mammals. Nature, Lond. 196, 446-450.

Foote, W.D. \& Thibault, C. (1969) Recherches experimentales sur la maturation in vitro des ovocytes de truie et de veau. Annls Biol. anim. Biochim. Biophys. 9, 329-349.

Fowler, R.F. \& Edwards, R.G. (1973) The genetics of early human development. In Progress in Medical Genetics, Vol. 9, pp. 49-112. Eds. A. G. Steinberg and A. C. Bearn. Grune \& Stratton, New York.

Franchi, L.L., MANDL, A.M. \& Zuckerman, S. (1962) The development of the ovary and the process of oogenesis. In The Ovary, Vol. 1, pp. 1-88. Ed. S. Zuckerman. Academic Press, New York.

GreEnwald, G.S. (1960) The effects of unilateral ovariectomy on follicular maturation in the hamster. Endocrinology 66, 89-95.

Greenwald, G.S. \& Peppler, R.D. (1968) Prepubertal and pubertal changes in the hamster ovary. Anat. Rec. 161, 447-458.

Gwatkin, R.B.L. \& HaidRi, A.A. (1973) Requirements for the maturation of hamster oocytes in vitro. Expl Cell Res. 76, 1-7.

Iwamatsu, T. \& Chang, M.C. (1972) Sperm penetration in vitro of mouse oocytes at various times during maturation. F. Reprod. Fert. 31, 237-247.

KRAGT, C.L. \& DAHLGREN, J. (1972) Development of normal regulation of follicle stimulating hormone (FSH) secretion. Neuroendocrinology 9, 30-40.

Lemon, J.G. \& Morton, R.M. (1968) Oogenesis in the golden hamster (Mesocricetus auratus). A study of the first meiotic prophase. Cytogenetics 7, 376-389.

Meijs-Roelofs, H.M.A., Uilenbroek, J.T.J., Osman, P. \& Welschen, R. (1973) Serum levels of gonadotrophins and follicular growth in prepubertal rat. In The Development and Maturation of the Ovary and its Functions, pp. 3-11. Ed. H. Peters. Excerpta Medica, Amsterdam.

Moore, G.P.M., Lintern-Moore, S., Peters, H. \& Faber, M. (1974) RNA synthesis in the mouse oocyte. F. Cell Biol. 60, 416-422.

OJeDa, S.R. \& Ramirez, V.D. (1972) Plasma level of LH and FSH in maturing rats: response to hemigonadectomy. Endocrinology 90, 466-472.

Pedersen, T. \& Peters, H. (1968) Proposal for a classification of oocytes and follicles in the mouse ovary. 7. Reprod. Fert. 17, 555-557.

Reiter, E.D., Goldenberg, R.L., Vaitukaitis, J.L. \& Ross, G.T. (1972) A role for endogenous estrogen in normal ovarian development in the neonatal rat. Endocrinology 91, 1537-1539.

STERN, S., RAYYIS, A. \& KENNEDY, J.F. (1972) Incorporation of amino acids during maturation in vitro by the mouse oocyte: effect of puromycin on protein synthesis. Biol. Reprod. 7, 341-346.

SzYBEK, K. (1972) In vitro maturation of oocytes from sexually immature mice. F. Endocr. 54, 527-528.

TSafriri, A. \& Ghanning, C.P. (1975) An inhibitory influence of granulosa cells and follicular fluid upon porcine oocyte meiosis in vitro. Endocrinology 96, 922-927.

ZeILMAKER, G.H. \& Verhamme, C.M.P.M. (1974) Observations on rat oocyte maturation in vitro: morphology and energy requirements. Biol. Reprod. 11, 145-152. 